\title{
Cerebrospinal Fluid Pleocytosis in Critical Care Patients With Seizures
}

\author{
Carly Scramstad, Alan C. Jackson
}

\begin{abstract}
Objectives: To assess the etiology of cerebrospinal fluid (CSF) pleocytosis in critical care patients with seizure(s) or status epilepticus (SE). Many previous studies, some performed decades ago, concluded that CSF pleocytosis may be entirely attributable to seizure activity. Methods: We undertook a retrospective chart review of adult patients with an admitting or acquired diagnosis of seizure(s) or SE in critical care units at the Winnipeg Health Sciences Centre between 2009 and 2012. Patients were identified through a critical care information database at a tertiary care center. We limited our study to patients who had lumbar punctures at our center within 5 days of seizure(s) or SE. Results: Of 426 patients with seizures in critical care units, 51 met the inclusion criteria. Seizure subtypes included focal seizures (5 or 10\%), generalized seizures (14 or 27\%), and SE (32 or 63\%). Twelve (seven with SE) of the 51 (24\%) were found to have CSF pleocytosis. A probable etiological cause for the CSF pleocytosis was identified in all 12 cases. Conclusions: We conclude that seizures do not directly induce a CSF pleocytosis. Instead, the CSF pleocytosis more likely reflects the underlying acute or chronic brain process responsible for the seizure(s). This was not readily apparent in early studies without magnetic resonance imaging (MRI) of the brain and currently available laboratory investigations. An etiological cause of CSF pleocytosis must always be sought when patients present with seizures and it should never be assumed that seizures are the cause.
\end{abstract}

RÉSUMÉ: Pléiocytose du liquide céphalo-rachidien chez les patients admis aux soins intensifs qui présentent des crises convulsives. Objectifs: Le but de l'étude était d'évaluer l'étiologie de la pléiocytose du liquide céphalo-rachidien chez les patients admis aux soins intensifs qui présentent des crises convulsives ou qui sont en état de mal épileptique (EME). Plusieurs études antérieures, dont certaines ont été réalisées il y a des décennies, ont conclu que la pléiocytose du LCR peut être entièrement attribuable à l'activité épileptique. Méthodologie: Nous avons réalisé une revue rétrospective des dossiers de patients adultes admis aux soins intensifs, chez qui un diagnostic de crise convulsive ou d'EME avait été posé à l'admission ou pendant l'hospitalisation au Winnipeg Health Sciences Centre entre 2009 et 2012. Les patients ont été identifiés dans une base de données d'information sur les patients hospitalisés aux soins intensifs dans un centre de soins tertiaires. Nous avons restreint notre étude aux patients qui avaient eu une ponction lombaire dans notre centre en dedans de 5 jours de la crise convulsive ou de l'EME. Résultats: Parmi les 426 patients ayant présenté des crises convulsives à l'unité de soins intensifs, 51 rencontraient les critères d'inclusion de l'étude. Les sous-types de crises convulsives étaient les suivantes: des crises focales chez 5 patients (10\%), des crises généralisées chez 14 patients (27\%) et un EME chez 32 patients (63\%). Parmi les 51 patients de l'étude, 12 patients (24\%) avaient une pléiocytose du LCR et parmi eux, 7 avaient présenté un EME. La cause étiologique probable de la pléiocytose du LCR a été identifiée chez ces 12 patients. Conclusions: Les crises convulsives n'induisent pas directement une pléiocytose du LCR. La pléiocytose du LCR reflète plutôt un processus aigu ou chronique sous-jacent au niveau du cerveau, un processus qui serait probablement responsable de ces crises. Ceci n'était pas évident dans les études antérieures effectuées lorsque l'imagerie par résonance magnétique et les analyses de laboratoire actuelles n'étaient pas disponibles. L'étiologique de la pléiocytose doit toujours être recherchée quand un patient présente des convulsions et on ne devrait jamais présumer que la crise convulsive en est la cause.

Keywords: cerebrospinal fluid pleocytosis, epilepsy, seizure, status epilepticus

doi:10.1017/cjn.2016.442

Can J Neurol Sci. 2017; 44: 343-349

It has long been recognized that a cerebrospinal (CSF) pleocytosis may be observed after the occurrence of one or more epileptic seizures. ${ }^{1-12}$ In many cases, it is readily apparent that the CSF pleocytosis is directly related to the etiology of the seizure(s). In other cases, and with support from a large number of publications in the literature, clinicians may conclude that a CSF pleocytosis was likely caused by the seizures themselves. ${ }^{1-12}$ In light of important advances in diagnosing brain diseases with modern neuroimaging (e.g. magnetic resonance imaging), improved diagnosis of central nervous system infections using molecular techniques, and recognition of autoimmune encephalitis, we believed a reevaluation was needed. We sought to determine whether CSF pleocytosis associated with seizures is due to the underlying cause of the seizures or if there is strong evidence that seizures themselves can actually induce a CSF pleocytosis. We evaluated patients admitted to critical care units; many of the patients had status epilepticus (SE). Previous reports indicate that CSF pleocytosis tends to follow repeated or prolonged seizures. ${ }^{5,6}$ If seizures themselves can induce CSF pleocytosis, then this phenomenon is expected to be more readily observed in a patient group with SE.

From the Departments of Internal Medicine (Neurology) (CS) and Medical Microbiology (ACJ), University of Manitoba, Winnipeg, Manitoba, Canada.

Received July 27, 2016. Final Revisions Submitted SePtember 11, 2016. Date of ACCEPTANCE OCTOBER 3, 2016.

Correspondence to: Alan C. Jackson, Health Sciences Centre, GF-543, 820 Sherbrook Street, Winnipeg, MB R3A1R9 Canada, Email: ajackson2@hsc.mb.ca 


\section{METHODS}

\section{Study Design and Patient Identification}

We completed a retrospective chart review of adult patients (age 18 years or older) with seizures or SE in the medical and surgical intensive care units of the Winnipeg Health Sciences Centre, which is an urban tertiary care centre, over the 4-year period between January 2009 and December 2012. Patients were identified through the Critical Care Information Management Database at the Health Sciences Centre in Winnipeg, Canada. The database maintains a record of all patients admitted to critical care units with admission and acquired diagnoses (see http://www. wrha.mb.ca/prog/criticalcare/research.php for details). This database has previously been described in theliterature. ${ }^{13}$ Each critical care patient has a diagnostic summary completed by the attending physician, which are reviewed by research nurses who input the information into a database. At discharge, data sheets are audited and any missing information is obtained through review of the chart. A database management committee supervises all aspects of the database, including software, data set, data verification, and collection procedures. $^{13}$

\section{Laboratory Determination of CSF Parameters}

CSF pleocytosis was defined as a CSF white blood cell (WBC) count $>5 \times 10^{6} / \mathrm{L}$, as per the laboratory range and consistent with conventional definitions. All CSF counts at our center were counted manually using a Neubauer chamber with a coefficient of variation $(\mathrm{CV})$ of $45 \%(+90 \%$ for $2 \mathrm{CV})$ with the same cell concentration. $^{14}$

\section{Inclusion and Exclusion Criteria}

Patients were included for analysis if they underwent lumbar puncture for CSF analysis within 5 days of their first seizure or at the beginning of the onset of SE. Only the first lumbar puncture results were included in the analysis. Patients were excluded if their CSF analysis did not include a cell count and differential, Gram stain, and culture. To ensure the uniformity of laboratory analysis, patients whose lumbar puncture was performed at a different site (i.e. before referral to our site) were excluded.

\section{ReSUlts}

A total of 426 patients admitted to the medical and surgical intensive care units were given the diagnosis of seizure during the study period. Of these, 51 met the study inclusion and exclusion criteria (Figure 1).

\section{Patient Characteristics}

Information on the patients' history including age, seizure semiology, seizure duration, time from seizure to lumbar puncture, and the treating team's leading diagnosis were extracted from the medical charts. Laboratory investigations, electroencephalography, and computed tomography (CT) and/or MRI data were also collected. The clinical characteristics of all patients are shown in Table 1. The mean time interval between the noted seizure and lumbar puncture was 34.6 hours. Nine patients had previously diagnosed epilepsy.
Total patients identified in intensive care unit database: 42

Excluded: 347

No lumbar puncture: 326

Incomplete chart or chart not available for review during the study period: 21

Patients with lumbar puncture: 79
Excluded: 28

Patients in the intensive care unit with lumbar puncture but without seizure(s): 4

Time from seizure onset to lumbar puncture $>5$ days: 13

Lumbar puncture performed, but cell count with differential and/or Gram stain not included: 7

Lumbar puncture performed at a different centre: 4
Patients included in analysis: $\mathbf{5 1}$

Figure 1: Consolidated Standards of Reporting Trials-style diagram showing how study patients were selected.

Seizures were classified according to the 2010 International League Against Epilepsy (ILAE) definition. ${ }^{15}$ Although the ILAE definitions from 1989 continue to be in common use in clinical

Table 1: Patient characteristics of 51 patients with seizures and postictal CSF analyses

\begin{tabular}{|c|c|}
\hline Characteristic & \\
\hline \multicolumn{2}{|l|}{ Age, years } \\
\hline Range & $19-79$ \\
\hline Median & 47 \\
\hline \multicolumn{2}{|l|}{ Sex, no. (\%) } \\
\hline Female & $28(55)$ \\
\hline Male & $23(45)$ \\
\hline \multicolumn{2}{|l|}{ Etiology, no. (\%) } \\
\hline Provoked & $33(65)$ \\
\hline Brain tumor & $1(2)$ \\
\hline Eclampsia & $1(2)$ \\
\hline Hypoxic ischemic & $1(2)$ \\
\hline Pituitary apoplexy & $1(2)$ \\
\hline Brain trauma & $2(4)$ \\
\hline Hypertensive encephalopathy & $2(4)$ \\
\hline Cerebrovascular disease & $2(4)$ \\
\hline Infectious & $3(6)$ \\
\hline Inflammatory & $4(8)$ \\
\hline Toxic/metabolic & $16(32)$ \\
\hline Epileptic & $18(35)$ \\
\hline Structural/metabolic & $5(10)$ \\
\hline Genetic or unknown & $13(25)$ \\
\hline
\end{tabular}


Table 2: Seizure characteristics of 51 patients with seizures and postictal CSF analyses

\begin{tabular}{l|c|c}
\hline Seizure type & With pleocytosis & Without pleocytosis \\
\hline Generalized, no. (\%) & $3(6)$ & $11(22)$ \\
\hline Focal, no. (\%) & $2(4)$ & $3(6)$ \\
\hline SE, no. $(\%)$ & $7(14)$ & $25(49)$ \\
\hline CSE $(\%)$ & $3(6)$ & $18(35)$ \\
\hline FEBC $(\%)$ & $2(4)$ & $2(4)$ \\
\hline EPC $(\%)$ & $0(0)$ & $1(2)$ \\
\hline NCSE $(\%)$ & $2(4)$ & $4(8)$ \\
\hline
\end{tabular}

$\mathrm{CSE}=$ convulsive status epilepticus; $\mathrm{EPC}=$ epilepsia partialis continua; $\mathrm{FEBC}=$ focal evolving to bilateral convulsive , NCSE $=$ nonconvulsive status epilepticus.

practice, the 2010 definitions use more accurate and evidence based terminology. Seizures were broadly classified by mode of onset into generalized, focal, or SE (Table 2). Isolated seizures were then classified into provoked seizures and epileptic seizures, with epilepsy further subdivided into structural/metabolic or genetic/unknown subtypes. SE was defined using the 2015 definition of the ILAE Task Force on Classification of Status Epilepticus. ${ }^{16} \mathrm{SE}$ was further classified into SE with and without prominent motor symptoms.

Of the 51 patients who met the inclusion/exclusion criteria, 12 patients had a CSF pleocytosis and all had a probable etiology for the CSF pleocytosis related to an underlying acute or chronic brain disorder (Table 3).

\section{Discussion}

A CSF pleocytosis was noted after the occurrence of seizures in a report from 1926 by Patterson and Levi ${ }^{1}$ and other reports soon followed. ${ }^{2,3}$ A systematic literature review (Table 4) reveals a variety of studies (Table 5), many performed decades ago, that have led to a widely held belief that seizures themselves may be the cause of CSF pleocytosis in a minority of cases.

In a critical care population, we identified 51 patients over a 4-year period with seizures and postictal CSF analyses that met

Table 3: Probable cause of CSF pleocytosis in 12 patients

\begin{tabular}{|c|c|c|c|c|}
\hline Category & $\begin{array}{l}\text { Etiology with citation(s) justifying } \\
\text { cause of CSF pleocytosis }\end{array}$ & $\begin{array}{l}\text { No. of } \\
\text { cases }\end{array}$ & $\begin{array}{c}\text { CSF WBC } \\
\operatorname{count} \times 10^{6} / \mathrm{L}\end{array}$ & Brain MRI result \\
\hline \multicolumn{5}{|c|}{ Inflammatory } \\
\hline & Multiple sclerosis ${ }^{17,18}$ & 2 & 31 & Patient 1: Multiple areas of demyelination and secondary cerebral atrophy. \\
\hline & & & 6 & Patient 2: Extensive supra- and infratentorial demyelinating plaques \\
\hline & $\begin{array}{l}\text { Immune reconstitution } \\
\text { inflammatory syndrome }{ }^{19}\end{array}$ & 1 & 23 & $\begin{array}{l}\text { Scattered areas of increased T2 signal intensity diffusely throughout the subcortical } \\
\text { white matter. Diffuse leptomeningeal enhancement. }\end{array}$ \\
\hline \multicolumn{5}{|l|}{ Infectious } \\
\hline & Cryptococcal meningitis ${ }^{20}$ & 1 & 109 & ND. CT scan of the head was normal. \\
\hline & $\begin{array}{l}\text { Meningoencephalitis (presumed } \\
\text { viral) }\end{array}$ & 1 & 117 & Diffuse pial enhancement and increased FLAIR signal intensity over the cerebral sulci.* \\
\hline & HIV infection ${ }^{22}$ & 1 & 8 & ND \\
\hline \multicolumn{5}{|l|}{ Stroke } \\
\hline & Parietal infarct ${ }^{23,24}$ & 1 & 12 & Edema in right frontoparietal lobe with area of acute infarct in the right parietal cortex. \\
\hline \multicolumn{5}{|l|}{ Hypoxia } \\
\hline & $\begin{array}{l}\text { Global hypoxic-ischemic brain } \\
\text { injury }\end{array}$ & 1 & 9 & $\begin{array}{l}\text { Restricted diffusion throughout the cerebral cortex. involving the frontal, parietal, } \\
\text { temporal and occipital lobes. }\end{array}$ \\
\hline \multicolumn{5}{|c|}{ Drug intoxication } \\
\hline & Cocaine intoxication ${ }^{27,28}$ & 1 & 10 & $\begin{array}{l}\text { Abnormal high intense signal of the subarachnoid space detected in FLAIR sequence. } \\
\text { The MRI scan was performed postlumbar puncture.* }\end{array}$ \\
\hline \multicolumn{5}{|c|}{ Pituitary apoplexy } \\
\hline & Pituitary apoplexy ${ }^{29,30}$ & 1 & 26 & $\begin{array}{l}\text { A 14- to } 15-\mathrm{mm} \text { lesion centered in the sella turcica extending just into the suprasellar } \\
\text { cistern. The lesion demonstrates increased signal intensity on the T1-weighted } \\
\text { images (also high attenuation on an uninfused CT scan). On the FLAIR images and } \\
\text { the diffusion-weighted images, there is subtle increased signal intensity in the cortex } \\
\text { of the cingulate gyrus, insular cortex, and thalamus on the left. }\end{array}$ \\
\hline \multicolumn{5}{|l|}{ Traumatic } \\
\hline & Posttraumatic $^{31}$ & 1 & 21 & Normal \\
\hline \multicolumn{5}{|l|}{ Neoplastic } \\
\hline & Brain metastases $^{32}$ & 1 & 6 & $\begin{array}{l}\text { Multiple intracranial nodules without evidence of central restricted diffusion to support } \\
\text { alternate considerations such as infectious etiology. }\end{array}$ \\
\hline
\end{tabular}

FLAIR = fluid-attenuated inversion recovery $\mathrm{ND}=$ not done.

*The significance of these findings is uncertain and could be attributable to the paramagnetic effect of supplemental oxygen. ${ }^{33}$ 
Table 4: CSF pleocytosis search strategy

\begin{tabular}{|c|c|}
\hline Exposure & Seizure \\
\hline Outcome & CSF pleocytosis \\
\hline \multirow[t]{2}{*}{ Population } & Adult and pediatric populations included in the initial literature search \\
\hline & Pediatric populations excluded in the final literature review \\
\hline \multirow[t]{3}{*}{ Time } & Search parameters included articles from 1980 to present \\
\hline & Articles from before 1980 that were identified from citation lists of retrieved articles were included if relevant \\
\hline & Search performed and updated from January 2014 to January 2016 \\
\hline \multirow[t]{3}{*}{ Article types } & All article types \\
\hline & Abstract available \\
\hline & English language \\
\hline Inclusion criteria & Articles focusing on CSF parameters after seizure \\
\hline \multirow[t]{4}{*}{ Exclusion criteria } & Review articles without specific patient data \\
\hline & Articles with CSF parameters in which cell counts were not provided \\
\hline & Articles focusing on management of seizure or SE \\
\hline & Book chapters \\
\hline \multirow[t]{4}{*}{ Information sources } & SCOPUS \\
\hline & PubMed \\
\hline & Cochrane Review \\
\hline & Citation lists of retrieved articles \\
\hline \multirow[t]{7}{*}{ Search terms } & Cerebrospinal fluid \\
\hline & Seizures \\
\hline & SE \\
\hline & Epilepsy \\
\hline & Pleocytosis \\
\hline & MRI \\
\hline & {$[\mathrm{MeSH}]$ terms were used for each search } \\
\hline
\end{tabular}

the study inclusion criteria. Twelve of these 51 patients $(23.5 \%)$ had a CSF pleocytosis, and we identified a probable cause for the pleocytosis in all of these cases (Table 3). Some of the established etiologies had very strong associations with the presence of CSF pleocytosis (e.g. cryptococcal meningitis), whereas for others such as cocaine intoxication there was evidence with less strong support in the literature. ${ }^{27,28}$ A nonprogressive vasculitis may explain CSF pleocytosis in cocaine intoxication. ${ }^{27,28}$ Structural lesions were demonstrated with MRI in eight of the 10 cases $(80 \%)$ in which this imaging was performed (Table 3); hence, we did not find a single case of CSF pleocytosis in which the seizures themselves were the only identified probable cause of the pleocytosis.

Many classical studies, mostly performed decades ago, indicated that $2 \%$ to $20 \%$ of patients had a CSF pleocytosis in association with seizures in the absence of an identified underlying brain process. We reevaluated these heterogeneous studies that had variable definitions of CSF pleocytosis (Table 5). Many of these reports excluded patients with known underlying causes for CSF pleocytosis such as infection, inflammation, trauma, or neoplastic processes, and the exclusion criteria were not always clearly laid out. It is interesting to note that alcohol withdrawal was not infrequently associated with seizures and CSF pleocytosis (14 patients in two reports) (Table 5). We suspect that this may, at least in part, be related to unrecognized head injuries resulting in seizures and CSF pleocytosis as previously suggested. ${ }^{11}$ The relationship of CSF pleocytosis with seizures related to isoniazid intoxication in two of the reports (involving five patients) ${ }^{4,5}$ is interesting. This has been subsequently reported in an additional case report. ${ }^{34}$ Isoniazid intoxication may induce a CSF pleocytosis through a mechanism that has not yet been defined. Observations from these studies gave rise to the widely held and accepted concept that in a minority of cases seizures themselves are the probable cause of CSF pleocytosis through unknown mechanisms. It is likely that potential causes of the CSF pleocytosis were underrecognized, in part, because of utilization of insensitive imaging investigations (e.g. CT scans) from a previous era.

Limitations of this study include the retrospective design, heterogeneous seizure population, and variable time from seizure to lumbar puncture (mean, 34.6 hours). Strengths of the study include the critical care setting because these patients are typically more thoroughly investigated and have more detailed charts than non-critical care patients. In addition, studying patients with the most severe seizure types such as SE, ensures CSF pleocytosis was not overlooked by only assessing self-limited or milder seizure types. Although our patient selection represents a referral bias, this bias aims to identify the patients most likely to have CSF 
Table 5: Key reports in adult patients with seizures and CSF pleocytosis

\begin{tabular}{|c|c|c|c|c|}
\hline Authors and year & Seizure type & $\begin{array}{l}\text { Occurrence of CSF } \\
\text { pleocytosis }\end{array}$ & $\begin{array}{l}\text { Identified probable cause for CSF } \\
\text { pleocytosis }\end{array}$ & Authors' conclusions \\
\hline $\begin{array}{l}\text { Aminoff and Simon } \\
(1980)^{4}\end{array}$ & $\begin{array}{l}\text { Motor SE } \\
\quad \text { (excluded absence, } \\
\text { myoclonic or partial status) }\end{array}$ & 5 of $65(7.7 \%)^{*}, \dagger$ & $\begin{array}{l}\text { - Unexplained (7), including } 2 \text { with } \\
\text { isoniazid intoxication }\end{array}$ & $\begin{array}{l}\text { SE-induced CSF pleocytosis may } \\
\text { develop. }\end{array}$ \\
\hline $\begin{array}{l}\text { Schmidley and } \\
\text { Simon }(1981)^{5}\end{array}$ & $\begin{array}{l}\text { Repeated GTC seizures ( } 4 \text { patients) } \\
\text { Generalized SE ( } 1 \text { patient) } \\
\text { Repeated GTC and focal } \\
\quad \text { seizures ( } 1 \text { patient) }\end{array}$ & $\begin{array}{l}6 \text { case reports among } \\
\text { about } 2000 \text { patients } \\
\text { with seizures }\end{array}$ & $\begin{array}{l}\text { - Unexplained (6), including } 3 \text { with } \\
\text { isoniazid intoxication }\end{array}$ & $\begin{array}{l}\text { Frequently repeated generalized } \\
\text { convulsions may cause CSF } \\
\text { pleocytosis. }\end{array}$ \\
\hline $\begin{array}{l}\text { Edwards et al } \\
\quad(1983)^{6}\end{array}$ & GTC seizures & $\begin{array}{l}2 \text { of } 98 \text { episodes }(2 \%) \\
\quad \text { in } 91 \text { patients } \dagger\end{array}$ & - Unexplained (2) & $\begin{array}{l}\text { CSF pleocytosis directly related to } \\
\text { seizures occurs, but is } \\
\text { uncommon. }\end{array}$ \\
\hline $\begin{array}{l}\text { Prokesch et al } \\
\qquad(1983)^{7}\end{array}$ & $\begin{array}{l}\text { Generalized or focal tonic } \\
\text { clonic or clonic activity }\end{array}$ & 29 of $102(28.4 \%)^{*}$, & $\begin{array}{l}\text { - Subdural hematomas (2) } \\
\text { - Bacterial meningitis (1) } \\
\text { - Stroke (6) } \\
\text { - Unexplained (20), including } 12 \\
\text { with alcohol withdrawal }\end{array}$ & $\begin{array}{l}\text { A CSF pleocytosis may be entirely } \\
\text { attributable to seizure activity. }\end{array}$ \\
\hline $\begin{array}{l}\text { Devinsky et al } \\
(1988)^{8}\end{array}$ & $\begin{array}{l}\text { Simple and complex partial and } \\
\text { GTC seizures }\end{array}$ & $\begin{array}{l}7 \text { of } 62(11.3 \%) \text { in } 27 \\
\text { patients }\end{array}$ & - Unexplained (7) & $\begin{array}{l}\text { CSF pleocytosis was most likely a } \\
\text { direct result of the seizures. }\end{array}$ \\
\hline $\begin{array}{l}\text { Barry and Hauser } \\
\quad(1994)^{11}\end{array}$ & SE; all seizure types and etiologies & 21 of $138(15.2 \%)^{*}$ & $\begin{array}{l}\text { - Acute trauma (2) } \\
\text { - Stroke (2) } \\
\text { - Hypoxia (1) } \\
\text { - Meningitis (6) } \\
\text { - Encephalitis (5) } \\
\text { - Unexplained (5), including } 2 \text { with } \\
\text { alcohol withdrawal }\end{array}$ & $\begin{array}{l}\text { CSF pleocytosis may be attributed } \\
\text { to SE after all other causes have } \\
\text { been eliminated. }\end{array}$ \\
\hline Peltola et al $(2002)^{9}$ & $\begin{array}{l}\text { Previously undiagnosed GTC } \\
\text { seizures or partial secondarily } \\
\text { generalized seizures }\end{array}$ & 6 of $37(16.2 \%) \S$ & - Unexplained (6) & $\begin{array}{l}\text { Seizures may cause CSF } \\
\text { pleocytosis. }\end{array}$ \\
\hline $\begin{array}{l}\text { Tumani et al } \\
\qquad(2015)^{10}\end{array}$ & $\begin{array}{l}\text { All seizure types and } \\
\text { etiologies except SE }\end{array}$ & 19 of $309(6.1 \%) \|$ & $\begin{array}{l}\text { - Unable to determine from this } \\
\text { report }\end{array}$ & $\begin{array}{l}\text { CSF pleocytosis is infrequently } \\
\text { observed in patients with } \\
\text { seizures. }\end{array}$ \\
\hline Current study & All seizure types & 12 of $51(23.5 \%)$ & $\begin{array}{l}\text { - Autoimmune/inflammatory (3) } \\
\text { - Infection (3) } \\
\text { - Brain metastases (1) } \\
\text { - Hypoxic-ischemic brain injury (1) } \\
\text { - Cocaine intoxication (1) } \\
\text { - Pituitary apoplexy (1) } \\
\text { - Posttraumatic (1) } \\
\text { - Neoplastic (1) }\end{array}$ & $\begin{array}{l}\text { Seizures do not directly induce CSF } \\
\text { pleocytosis. }\end{array}$ \\
\hline
\end{tabular}

$\mathrm{GTC}=$ general tonic-clonic.

*We have excluded all cases in which the authors defined CSF pleocytosis as a WBC $>1 \times 10^{6}$ polymorphonuclear leukocyte/l with $<5 \times 10^{6}$ WBC/1.

$\dagger$ This study excluded patients who had known diseases associated with CSF pleocytosis.

$\ddagger$ We excluded a patient with subarachnoid hemorrhage with bloody CSF.

$\S \mathrm{CSF}$ pleocytosis was defined as $>3 \times 10^{6} \mathrm{WBC} / 1$. Patients with seizures resulting from electrolyte disturbances, metabolic causes, acute brain disease, or trauma were excluded. Five patients were diagnosed with cerebral tumors.

IICSF pleocytosis was defined as $>4 \times 10^{6} \mathrm{WBC} / \mathrm{l}$.

pleocytosis given the type and severity of illnesses seen in a critical care setting.

Previous studies have suggested, but do not provide supportive evidence, that seizures may cause structural breakdown of the blood-brain barrier (BBB), leading to CSF pleocytosis. ${ }^{11,12}$ Although BBB dysfunction with seizures is very well-documented, the available evidence does not provide an explanation for the presence of cells in the CSF. ${ }^{35-37}$ Numerous experimental models have established BBB dysfunction in the setting of seizures by showing extravasation of albumin, but not of cells, out of the blood vessels. In fact, one study showed that "neither acute-induced nor chronic seizures correlate with WBC brain parenchymal migration while albumin and [immunoglobulin]G brain leakage is a hallmark of acute and chronic seizures." 38 This indicates that BBB dysfunction with seizures is sufficient to lead to extravasation of smaller molecules, but not of larger blood components such as cells. This is an area requiring further investigation, but currently a clear BBB mechanism for induction of CSF pleocytosis following seizures cannot be confirmed.

There is an accumulating body of research evaluating whether seizures in the absence of an underlying brain process can induce inflammation in the central nervous system and CSF. A recent meta-analysis concludes that "inflammatory pathways are involved in epilepsy" and looks at the role of cytokines in the blood, brain, and CSF. ${ }^{39}$ Certain cytokines (interleukin-17 and interleukin-22) that were found to be elevated in brain tissue can 
also cause BBB dysfunction and potentially attract inflammatory cells, but their role in producing a CSF pleocytosis has not been addressed. Current opinion on the mechanism of seizures indicates that epileptic seizures arise as an imbalance between excitatory and inhibitory forces in the brain. ${ }^{40}$ The role of inflammation in this process and the mechanism by which seizures are initiated, sustained, and terminated are unknown. ${ }^{41,42}$ The lack of a clear understanding of these mechanisms complicates our understanding of the inflammatory effect of seizures on the brain at a cellular and tissue level.

A patient's underlying acute brain pathology or, less commonly, a chronic brain process, provides the best explanation for both the occurrence of seizures and CSF pleocytosis. Many acute pathologies such as meningitis, trauma, and stroke are wellknown to cause both seizures and CSF pleocytosis. We conclude that seizures, in the absence of an underlying acute or chronic brain process, are very unlikely to be the cause of postictal CSF pleocytosis and that with appropriate investigations an underlying cause for CSF pleocytosis can be found for most patients. It is unclear if seizures themselves are at all capable of directly inducing a CSF pleocytosis. However, if this actually occurs, then it must occur very rarely and seizures should never be assumed to be the cause of a CSF pleocytosis. Appropriate investigations, including neuroimaging and other laboratory investigations, should always be performed to exclude treatable causes.

\section{ACKNOWLEDGEMENTS AND Funding}

The Critical Care Information Management Database at the Winnipeg Health Sciences Centre is supported by the Department of Internal Medicine at the University of Manitoba.

\section{DisclosuRes}

CS and ACJ do not have anything to disclose.

\section{REFERENCES}

1. Patterson HA, Levi P. The spinal fluid in epilepsy: a study of fifty cases. Arch Neurol Psychiatry. 1926;15:353-64.

2. Neel AV. Cell count and protein content of the spinal fluid in epilepsy. Acta Psychiatr Neurol. 1931;6:221-9.

3. Lennox WG, Merritt HH. The cerebrospinal fluid in 'essential' epilepsy. J Neurol Psychopathol. 1936;17:97-106.

4. Aminoff MJ, Simon RP. Status epilepticus: causes, clinical features and consequences in 98 patients. Am J Med. 1980;69: 657-66.

5. Schmidley JW, Simon RP. Postictal pleocytosis. Ann Neurol. 1981:9:81-4.

6. Edwards R, Schmidley JW, Simon RP. How often does a CSF pleocytosis follow generalized convulsions? Ann Neurol. 1983;13:460-2.

7. Prokesch RC, Rimland D, Petrini JL Jr, Fein AB. Cerebrospinal fluid pleocytosis after seizures. South Med J. 1983;76:322-7.

8. Devinsky O, Nadi S, Theodore WH, Porter RJ. Cerebrospinal fluid pleocytosis following simple, complex partial, and generalized tonic-clonic seizures. Ann Neurol. 1988;23:402-3.

9. Peltola J, Laaksonen J, Haapala AM, Hurme M, Rainesalo S, Keranen T. Indicators of inflammation after recent tonic-clonic epileptic seizures correlate with plasma interleukin-6 levels. Seizure. 2002;11: 44-6.

10. Tumani H, Jobs C, Brettschneider J, Hoppner AC, Kerling F, Fauser S. Effect of epileptic seizures on the cerebrospinal fluid-a systematic retrospective analysis. Epilepsy Res. 2015;114:23-31.

11. Barry E, Hauser WA. Pleocytosis after status epilepticus. Arch Neurol. 1994;51:190-3.
12. Johnson KB, Michelson KA, Lyons TW, et al. Pediatric status epilepticus: how common is cerebrospinal fluid pleocytosis in the absence of infection? Seizure. 2014;23:573-5.

13. Bhaskaran J, Johnson E, Bolton JM, et al. Population trends in substances used in deliberate self-poisoning leading to intensive care unit admissions from 2000 to 2010. J Clin Psychiatry. 2015;76: e1583-9.

14. Karcher DS, McPherson RA. Henry's clinical diagnosis and management by laboratory methods, 23rd ed. New York: Elsevier; 2017.

15. Berg AT, Berkovic SF, Brodie MJ, et al. Revised terminology and concepts for organization of seizures and epilepsies: report of the ILAE Commission on Classification and Terminology, 20052009. Epilepsia. 2010;51:676-85.

16. Trinka E, Cock H, Hesdorffer D, et al. A definition and classification of status epilepticus-report of the ILAE Task Force on Classification of Status Epilepticus. Epilepsia. 2015;56:1515-23.

17. Luque FA, Jaffe SL. Cerebrospinal fluid analysis in multiple sclerosis. Int Rev Neurobiol. 2007;79:341-56.

18. Karussis D. The diagnosis of multiple sclerosis and the various related demyelinating syndromes: a critical review. J Autoimmun. 2014;48-49:134-42.

19. Walker NF, Scriven J, Meintjes G, Wilkinson RJ. Immune reconstitution inflammatory syndrome in HIV-infected patients. HIV AIDS (Auckl ). 2015;7:49-64.

20. Makadzange AT, McHugh G. New approaches to the diagnosis and treatment of cryptococcal meningitis. Semin Neurol. 2014;34: 47-60.

21. Steiner I, Budka H, Chaudhuri A, et al. Viral meningoencephalitis: a review of diagnostic methods and guidelines for management. Eur J Neurol. 2010;17:999-e57.

22. Spudich SS, Nilsson AC, Lollo ND, et al. Cerebrospinal fluid HIV infection and pleocytosis: relation to systemic infection and antiretroviral treatment. BMC Infect Dis. 2005;5:98.

23. Sornas R, Ostlund $H$, Muller R. Cerebrospinal fluid cytology after stroke. Arch Neurol. 1972;26:489-501.

24. Britton M, Hultman E, Murray V, Sjoholm H. The diagnostic accuracy of CSF analyses in stroke. Acta Med Scand. 1983;214: 3-13.

25. Kaur C, Ling EA. Blood brain barrier in hypoxic-ischemic conditions. Curr Neurovasc Res. 2008;5:71-81.

26. Ballabh P, Braun A, Nedergaard M. The blood-brain barrier: an overview: structure, regulation, and clinical implications. Neurobiol Dis. 2004;16:1-13.

27. Alexopoulou A, Deutsch M, Dourakis SP. Acute neutrophilic meningitis treated successfully with corticosteroids. South Med J. 2003;96:912-3.

28. Gradon JD, Wityk R. Diagnosis of probable cocaine-induced cerebral vasculitis by magnetic resonance angiography. South Med J. 1995;88:1264-6.

29. Briet C, Salenave S, Chanson P. Pituitary apoplexy. Endocrinol Metab Clin North Am. 2015;44:199-209.

30. Wong SH, Das K, Javadpour M. Pituitary apoplexy initially mistaken for bacterial meningitis. BMJ Case Rep. 2013;2013:bcr2013009223.

31. Bakay RA, Sweeney KM, Wood JH. Pathophysiology of cerebrospinal fluid in head injury: part 1. Pathological changes in cerebrospinal fluid solute composition after traumatic injury. Neurosurgery. 1986;18:234-43.

32. Bigner SH. Cerebrospinal fluid (CSF) cytology: current status and diagnostic applications. J Neuropathol Exp Neurol. 1992;51: 235-45.

33. Anzai Y, Ishikawa M, Shaw DW, Artru A, Yarnykh V, Maravilla KR. Paramagnetic effect of supplemental oxygen on CSF hyperintensity on fluid-attenuated inversion recovery MR images. AJNR Am J Neuroradiol. 2004;25:274-9.

34. Ehsan T, Malkoff MD. Acute isoniazid poisoning simulating meningoencephalitis. Neurology. 1995;45:1627-8.

35. Gorter JA, van Vliet EA, Aronica E. Status epilepticus, blood-brain barrier disruption, inflammation, and epileptogenesis. Epilepsy Behav. 2015;49:13-6.

36. Ueno M, Chiba Y, Murakami R, Matsumoto K, Kawauchi M, Fujihara R. Blood-brain barrier and blood-cerebrospinal fluid barrier in normal and pathological conditions. Brain Tumor Pathol. 2016;33:89-96. 
37. van Vliet EA, Aronica E, Gorter JA. Blood-brain barrier dysfunction, seizures and epilepsy. Semin Cell Dev Biol. 2015;38:26-34.

38. Marchi N, Teng Q, Ghosh C, et al. Blood-brain barrier damage, but not parenchymal white blood cells, is a hallmark of seizure activity. Brain Res. 2010;1353:176-86.

39. de Vries EE, van den Munckhof B, Braun KP, van Royen-Kerkhof A, de JW, Jansen FE. Inflammatory mediators in human epilepsy: a systematic review and meta-analysis. Neurosci Biobehav Rev. 2016;63:177-90.
40. Staley K. Molecular mechanisms of epilepsy. Nat Neurosci. 2015;18: 367-72.

41. Trevelyan AJ, Muldoon SF, Merricks EM, Racca C, Staley KJ. The role of inhibition in epileptic networks. J Clin Neurophysiol. 2015;32:227-34.

42. de Curtis M, Avoli M. Initiation, propagation, and termination of partial (focal) seizures. Cold Spring Harb Perspect Med. 2015;5: a022368. 